Mason, D. J. \& Powelson, D. (1958). J. gen. Microbiol. 19, 65-70

\title{
Lysis of Myxococcus xanthus
}

\author{
By D. J. MASON* AND DOROTHY POWELSON
}

Department of Biological Sciences, Purdue University, Lafayette, Indiana, U.S.A.

SUMMARY : Myxococcus xanthus lyses not only in old cultures but also when suspended in solutions of monovalent cation salts. This lysis is slow at $37^{\circ}$ and lower temperatures, but is very rapid at $45^{\circ}$ and $60^{\circ}$. Organisms in distilled water do not lyse at any temperature. Lysis is more rapid at high $\mathrm{pH}$ values, in broth or in solutions of monovalent cation salts; it is optimal in $c .0 .03 \mathrm{M}$ solutions of the salts. During lysis the cell wall weakens and empty spherical protuberances develop at the ends or in the middle of the organism. Finally, the dense material of the protoplasm disappears except for an occasional granule, and only single or paired spherical ghosts remain.

Studies of the lysis of bacteria have been important in contributing to knowledge about cell walls. Much significant information has been obtained through the introduction of enzymes as lytic agents (Salton,1953; Salton 1956; Weibull, 1956), but the 'autolysis' of bacteria has also been an interesting aspect of cell lysis (Nomura \& Hosoda, 1956; Mitchell \& Moyle, 1956, 1957; Strange \& Dark, 1957). During a study of the cell wall of the myxobacteria, it was found that the organisms lysed readily. This paper discusses some conditions favouring lysis and demonstrates the morphology of the lysing cells.

\section{METHODS}

Myxococcus xanthus was used as a representative myxobacterial organism. Stock cultures were grown for 7 days at $30^{\circ}$ on a modified Noren's medium (Noren, 1952), solidified $1.5 \%(w / v)$ agar. The liquid medium contained $(w / v)$ trypticase (Baltimore Biological Laboratory, U.S.A.), 0.5; $\mathrm{K}_{2} \mathrm{HPO}_{4}, 0.25$; $\mathrm{NaCl}, 0.1 ; \mathrm{MgSO}_{4} .7 \mathrm{H}_{2} \mathrm{O}, 0.01$; traces of $\mathrm{Ca}\left(\mathrm{NO}_{3}\right)_{2}, \mathrm{FeSO}_{4}, \mathrm{MnSO}_{4}$. The $\mathrm{pH}$ value of the medium after autoclaving was $7 \cdot 2-7 \cdot 4$. All of the organisms used in the experiments were grown in $150 \mathrm{ml}$. volumes of the trypticase + salts medium in 1 litre flasks at $27^{\circ}$; the flasks were shaken at 100 strokes $(2 \cdot 25$ in. throw)/min. A strain of $M$. xanthus was used which grew diffusely in the liquid medium. This strain did not spread on agar solidified medium, but it retained the ability to form fruiting bodies and microcysts ( $J$. Adye, 1958 private communication). As source of inoculum, $5 \mathrm{ml}$. of culture were transferred to flasks of medium every $48 \mathrm{hr}$. The organisms used for experiments on lysis were from 48 to $60 \mathrm{hr}$. cultures, in the early part of the stationary phase of growth. They were washed with distilled water three times by centrifugation and finally resuspended in distilled water.

* Present address: Department of Microbiology, The Upjohn Company, Kalamazoo, Michigan, U.S.A. 
Changes in optical density were used to follow lysis and to obtain growth curves. These changes were observed with a Coleman model 14 spectrophotometer at $610 \mathrm{~m} \mu$. In tests for lysis, $3 \mathrm{ml}$. suspension of organisms were added to $3 \mathrm{ml}$. of solution under test. The optical density (OD) of this mixture was about $0 \cdot 8-0.9$ scale reading unit. The readings on duplicate tubes throughout the test never varied more than 0.02-0.03 OD unit. Results are expressed as the average of the duplicates.

The morphological changes which took place during lysis were followed by phase contrast and electron microscopy. Wet mounts of lysing organisms were observed with a Spencer $\times 97$ oil immersion bright high phase contrast objective. Photographs were taken at $\times 1500$ on Adox KB 14 film. Specimens were also prepared for ultra-thin sectioning. Non lysing or lysing organisms were fixed for $2 \mathrm{hr}$. at $25^{\circ}$ in $\mathrm{OsO}_{4}(2 \%, \mathrm{w} / \mathrm{v})$ solution in $\mathrm{pH} 7 \cdot 3$ veronal buffer. The organisms were dehydrated in ethanol and embedded in $n$-butyl methacrylate + methyl methacrylate $(9: 1)$. Sections were cut with a Porter-Blum microtome and examined in a Phillips electron microscope.

\section{RESULTS}

Figure 1 shows a typical growth curve of Myxococcus xanthus in the modified Noren's liquid medium. After the cultures reached the stationary growth phase, there was a gradual lysis. During this time, the $\mathrm{pH}$ value of the culture medium might go as high as $\mathrm{pH} \mathrm{8.5.} \mathrm{Similar} \mathrm{lysis} \mathrm{occurred} \mathrm{in} \mathrm{solutions} \mathrm{of}$ $\mathrm{NaCl}$, and was much more rapid at $45^{\circ}$ than at $27^{\circ}$. Figure 2 shows the rate and extent of lysis of washed organisms in different concentrations of $\mathrm{NaCl}$ at $45^{\circ}$, they lysed in almost all concentrations of $\mathrm{NaCl}$ tested, but the rate optimum was around $0.03 \mathrm{~m}$. Figure 3 compares the lysis of these organisms in the liquid medium in which they have been grown with lysis in $0 \cdot 04 \mathrm{M}-\mathrm{NaCl}$. There was no lysis in distilled water. The organisms also lysed in $0.03 \mathrm{M}$ solutions of $\mathrm{KBr}, \mathrm{NaF}, \mathrm{KCl}, \mathrm{K}_{2} \mathrm{SO}_{4}, \mathrm{Na}$ acetate, $\mathrm{NH}_{4} \mathrm{Cl},\left(\mathrm{NH}_{4}\right)_{2} \mathrm{SO}_{4}$ and $\mathrm{NH}_{4}$ acetate. The rate and extent of lysis varied with the anion in salts of monovalent cations, as shown in Fig. 4 for ammonium salts. However, the addition of divalent cation salts to suspensions did not result in lysis; solutions of $0.03 \mathrm{M}-\mathrm{FeSO}_{4}, \mathrm{MgCl}_{2}$ and $\mathrm{CaCl}_{2}$, and 0.01 to $0 \cdot 1 \mathrm{M}-\mathrm{MgSO}_{4}$ were tested. $\mathrm{MgSO}_{4}$ $(0.0025 \mathrm{M})$ added to the liquid medium completely inhibited lysis; $\mathrm{CaCl}_{2}$ did not. Takahashi \& Gibbons (1957) reported that small amounts of divalent cations helped a halophilic bacterium (Micrococcus denitrificans) maintain its cell wall and allowed it to survive in less than the normal minimum level of sodium chloride.

The rate and extent of lysis were determined at different temperatures in the broth from the stationary growth phase (Fig. 5); the optical density (OD) changes of suspensions in water are also shown. The OD of water suspensions increased as the temperature increased; in contrast, the OD of suspensions in the liquid medium decreased. The rate and extent of lysis in both was strikingly greater at $45^{\circ}$ and $60^{\circ}$ than at $37^{\circ}$. Similar results were obtained when the organisms were lysed in $0.03 \mathrm{M}-\mathrm{NaCl}$ at these temperatures. 
Lysis was affected by the $\mathrm{pH}$ value of the suspending solution. Two ml. of a washed suspension were added to $4 \mathrm{ml} .0 \cdot 05 \mathrm{M}$-veronal buffer $(0.03 \mathrm{M}$ final concentration). The veronal buffer $(\mathrm{pH} 7 \cdot 0-9 \cdot 0)$ was made by adjusting the

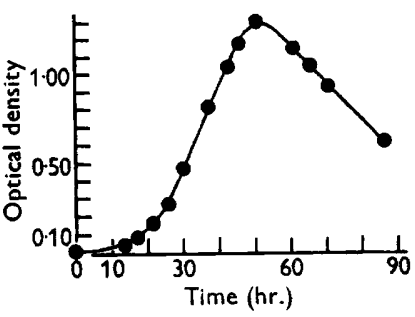

Fig. 1

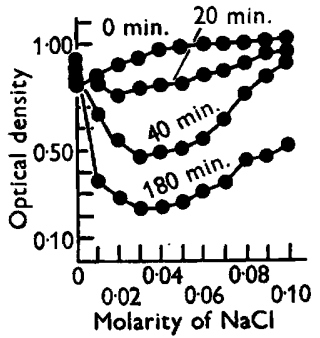

Fig. 2

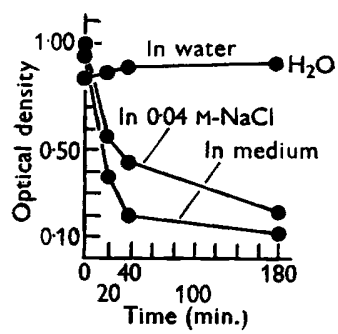

Fig. 3

Fig. 1. Growth curve, by optical density, of Myxococcus aanthus (disperse growing strain). Shaken in trypticase + salts medium at $27^{\circ}$.

Fig. 2. Lysis of $M$. xanthus suspended in $\mathrm{NaCl}$ solutions at $45^{\circ}$.

Fig. 3. Rate of lysis of $M$. xanthus at $45^{\circ}$ in water, $0 \cdot 04 \mathrm{M}-\mathrm{NaCl}$ or medium.

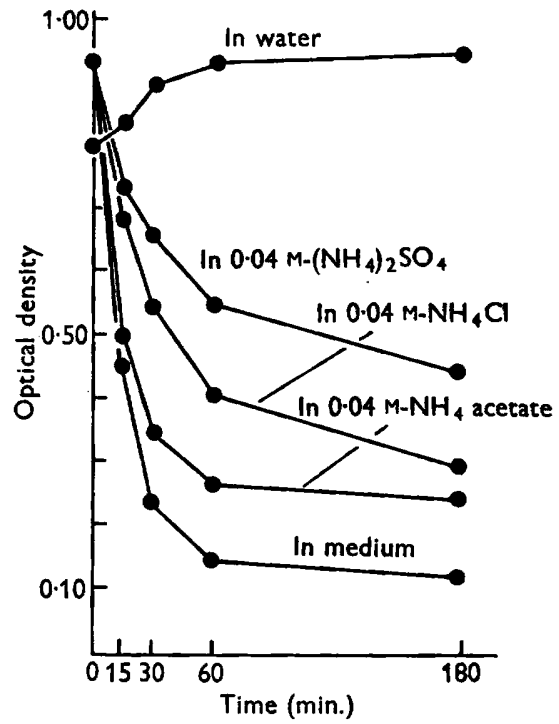

Fig. 4

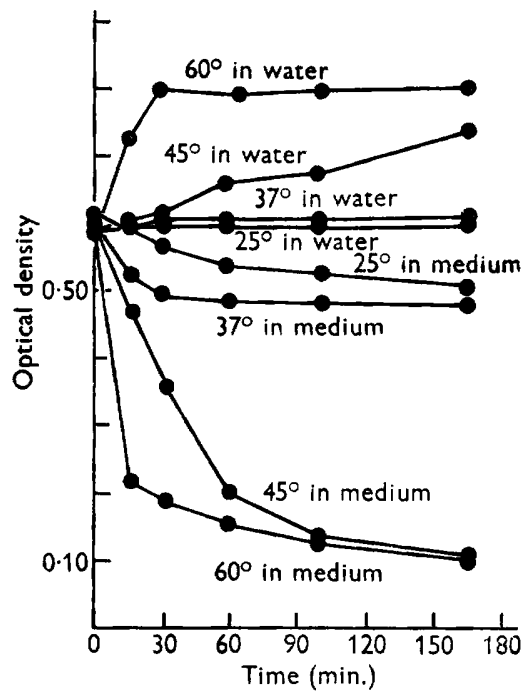

Fig. 5

Fig. 4. Lysis of $M$. xanthus at $45^{\circ}$ in $0.04 \mathrm{M}-\mathrm{NH}_{4} \mathrm{Cl},\left(\mathrm{NH}_{4}\right)_{2} \mathrm{SO}_{4}, \mathrm{NH}_{4}$ acetate: water or medium and broth.

Fig. 5. Lysis of $M$. xanthus in water or medium at different temperatures.

pH of $0 \cdot 1 \mathrm{M}-\mathrm{Na}$ veronal to the desired values with $0 \cdot 1 \mathrm{M}-\mathrm{HCl}$; then the buffer was diluted to $0.05 \mathrm{M}$-veronal. The rate and extent of lysis increased as the $\mathrm{pH}$ increased and lysis was almost instantaneous in other solutions with $\mathrm{pH}>\mathbf{9 \cdot 5}$, even at room temperature. 


\section{Morphology of the organisms during lysis}

Myxococcus xanthus grew as a long slender rod in the trypticase + salts medium. The organisms were slightly less than $0.5 \mu$ in diameter and 5-10 $\mu$ long. Thin sections of organisms from $48 \mathrm{hr}$. cultures showed that division occurred by a 'pinching-in' at the centre of the organism (Pl. 1, fig. 1). The organisms were surrounded by a wall which had an electron dense layer $c$. 75 $\AA$. on each side of a non-electron dense layer about $100 \AA$ thick. In non-lysing vegetative organisms these layers were never separated even when the organisms were poorly fixed.

Lysis was followed with phase-contrast microscopy. Plate 2, fig. 2, shows growing unaffected vegetative organisms from a $48 \mathrm{hr}$. culture. An organism ( $48 \mathrm{hr}$.) beginning to lyse developed a 'bulging' that was very characteristic of this lysis (Pl. 2, fig. 3). When the organisms were completely lysed, there was nothing visible except spherical ghosts in the suspension (Pl. 2, fig. 4). A thin section of lysing organisms ( $48 \mathrm{hr}$.) is shown in $\mathrm{Pl} .2$, fig. 5, while an air-dried preparation of lysing organisms is shown in Pl. 2, fig. 6. During lysis the cell walls seemed to weaken and bulbs formed usually at the ends of the organisms. When the lytic process was complete, spherical ghosts were left. Air-dried ghosts (Pl. 3, fig. 7) bore some resemblance to isolated cell walls (Mason, 1958). Thin sections of these ghosts suggested the presence of internal 'membranes' (Pl. 3, fig. 8).

The lysis of organisms from 38 to $60 \mathrm{hr}$. cultures by solutions of $\mathrm{NaCl}$ was not prevented by high concentrations of sucrose. However, Adye (1958) prevented lysis in medium from the stationary growth phase by adding sucrose or various gums. Mason observed that organisms from 12 to $20 \mathrm{hr}$. cultures rounded up without lysis when incubated on $0.5 \mathrm{M}$-sucrose at $30^{\circ}$ or after a day or so at $4^{\circ}$. The changes which occurred with $12 \mathrm{hr}$. organisms during a period of 90-120 min. at $30^{\circ}$ are illustrated by Pl. 3, figs. 9-12. Though the organisms remained dense they were not 'protoplasts' since they did not lyse when the suspension was diluted $1 / 10$ with distilled water. Thin sections of these organisms indicated that they might be highly vacuolated (Pl. 3, fig. 13). Although these round cells were not viable by our tests, Adye (1958) demonstrated viability when special methods were used.

\section{DISCUSSION}

While vegetative cells of Myxococcus xanthus lose the usual rod shape perhaps more easily than do eubacterial bacilli, the changes which occur appear to be similar in nature. It has been suggested (Park \& Strominger, 1957) that in eubacteria changes in the shape occur under conditions that seem to effect a loss or weakening of structural elements of the cell wall. The 'rabbit ears' and other oddly shaped cells, including round bodies, seen in suspensions of Escherichia coli during lysis promoted by lysozyme, penicillin or other agents, also appear during lysis of myxobacteria in $\mathrm{NaCl}$ solutions. Previously, the existence of a definite cell wall in myxobacteria has been questioned (e.g. van Iterson, 1947; Klieneberger-Nobel, 1948). On the other hand, different types of round bodies of myxobacteria other than microcysts have frequently been 
observed. Stanier (1947) reported that almost coccoid cells were present in cultures of Cytophaga johnsonii. Bachmann (1955) observed that 'small round bodies of low refractility' occurred chiefly in old cultures. Gray (1957) found two types of round cells, a small 'spheroid' and a larger cell that might be a 'spheroid' with layers of slime. The data we have presented indicate that myxobacteria have a structure that is morphologically identical with the cell walls of certain eubacteria. While we found that Escherichia coli and Bacillus cereus did not lyse or round up in the $\mathrm{NaCl}$ solutions, Mitchell \& Moyle (1956, 1957) observed that rapidly growing Staphylococcus aureus and $E$. coli became osmotically fragile in $\mathrm{NaCl}$ solutions and were stabilized by high concentrations of sugar. They demonstrated an autolytic system in the cell walls of $S$. aureus. It is possible that an autolytic enzyme or factor functions similarly in myxobacteria. One might be led to believe that this autolytic system and the protease in myxobacteria that is known to lyse eubacteria (their protoplasts but not cell walls) act synergistically to clear myxobacteria suspensions, especially when certain environmental factors hasten the death of the organisms; for example, the extent as well as the rate of lysis of the myxobacteria in the liquid medium and in $\mathrm{NaCl}$ solutions was much greater at $45^{\circ}$ and $60^{\circ}$ than at $37^{\circ}$. However, the absence of lysis in distilled water at these temperatures needs to be explained. If the organisms are being killed by heat the protease alone should bring about some lysis in water suspensions. Since this did not occur, perhaps we should consider the possibility that the protease is liberated from an inactive complex by the attack of an autolytic enzyme on its specific substrate. Then, only when conditions favour the action of the autolytic enzyme, can the protease hydrolyse the protein of the protoplasm.

The morphology of the boundary of a ghost of Myxococcus xanthus (Pl. 2, fig. 5; Pl. 3, fig. 8) suggests that most of the original cell wall remained after lysis. Mitchell \& Moyle (1956, 1957) showed that eubacteria may become osmotically fragile without loss of much structural cell-wall material. By way of contrast again, it may be pointed out that round bodies of $M$. xanthus produced in $0.5 \mathrm{M}$-sucrose (Pl. 3, fig. 12) are not osmotically fragile; we should like to know what stabilizes these cells. Since $M$. xanthus produces spherical microcysts on agar surfaces during fruiting-body formation, these round bodies may represent an aborted form of microcysts.

We wish to thank Mr J. G. Holt for the culture of Myxococcus xanthus which he isolated and identified. A predoctoral fellowship to D. J. Mason from the National Institutes of Health was appreciated. The discussions with Mr J. Adye, Mr J. G. Holt, and Miss Lois Nellis, who are also working with myxobacteria, were stimulating and helpful.

\section{REFERENCES}

Bachmann, B. J. (1955). Studies on Cytophaga fermentans, n.sp., a facultatively anaerobic lower Myxobacterium. J. gen. Microbiol. 13, 541.

GraY, P. H. H. (1957). The morphology of a species of the bacterial genus Cytophaga Winog. in culture. Canad. J. Microbiol. 3, 897.

ITERSON, W. VAN (1947). Some electron-microscopical observations on bacterial cytology. Biochim. biophys. Acta, 1, 527. 
KLIENEBerger-Nobel, E. (1948). Capsules and mucoid envelopes of bacteria. $J$. Hyg., Camb. 46, 345.

Mason, D. J. (1958). The cell rall of Myxobacteria. Ph.D. thesis. Purdue University, Lafayette, Indiana.

MrTCheLl, P., \& MoyLe, J. (1956). Autolytic 'protoplast' release in Bacterium coli. Nature, Lond. 178, 993.

Mrtcheld, P., \& Moyle, J. (1957). Autolytic release and osmotic properties of 'protoplasts' from Staphylococcus aureus. J. gen. Microbiol. 16, 184.

Nomura, M. \& Hosoda, J. (1956). Nature of the primary action of the autolysin of Bacillus subtilis. J. Bact. 72, 573.

Noren, B. (1952). Studies on Myxobacteria. I. Growth conditions. Svensk bot. Tidskr. 46, 324.

Park, J. T. \& Strominger, J. L. (1957). Mode of action of penicillin. Science, 125, 99.

Salton, M. R. J. (1953). Cell structure and the enzymic lysis of bacteria. J. gen. Microbiol. 9, 512.

Salton, M. R. J. (1956). Bacterial cell walls. In Bacterial Anatomy, Symp. Soc. gen. Microbiol. 6, 81.

Stanier, R. Y. (1947). Studies on nonfruiting myxobacteria. I. Cytophaga johnsonae, n.sp., a chitin decomposing myxobacterium. J. Bact. 53, 297.

Strange, R. E. \& Dark, F. A. (1957). A cell-wall lytic enzyme associated with spores of Bacillus species. J. gen. Microbiol. 16, 236.

Takahashi, I. \& Gibbons, N. E. (1957). Effect of salt concentration on the extracellular nucleic acids of Micrococcus halodenitrificans. Canad. J. Microbiol. 3, 687.

WeIBull, C. (1956). Bacterial protoplasts; their formation and characteristies. In Bacterial Anatomy, Symp. Soc. gen. Microbiol. 6, 111.

\section{EXPLANATION OF PLATES}

\section{Prate 1}

Fig. 1. Electron micrograph of a thin section of Myxococcus xanthus from a $48 \mathrm{hr}$. culture. Scale on print.

Plate 2

Figs. 2-6; scale on prints.

Fig. 2. Phase-contrast microscopy of vegetative cells of Myxococcus xanthus from a $48 \mathrm{hr}$. culture.

Fig. 3. Phase-contrast microscopy of $M$. xanthus $(48 \mathrm{hr}$.) after cells have partially lysed at $45^{\circ}$ in medium.

Fig. 4. Phase-contrast microscopy of $M$. xanthus ( $48 \mathrm{hr}$.) after cells have completely lysed at $45^{\circ}$ in medium.

Fig. 5. Electron micrograph of a thin section of $M$. xanthus $(48 \mathrm{hr}$.). Culture partially lysed in medium at $45^{\circ}$.

Fig. 6. Electron micrograph of air dried $M$. xanthus $(48 \mathrm{hr}$.). Culture partially lysed in medium at $45^{\circ}$. Chromium shadowed; negative print.

\section{Prate 3}

Figs. 7-13; scales on prints.

Fig. 7. Electron micrograph of air-dried Myxococcus xanthus $(48 \mathrm{hr}$.). Culture completely lysed in medium at $45^{\circ}$. Chromium shadowed; negative print.

Fig. 8. Electron micrograph of thin sections of cells $\left(48 \mathrm{hr}\right.$.) lysed in medium at $45^{\circ}$.

Figs. 9-11. Early stages of 'rounding-up' of $M$. xanthus (12. hr.). Cells in $0.5 \mathrm{M}$-sucrose at $30^{\circ}$ for $30-90 \mathrm{~min}$. Phase-contrast microscopy.

Fig. 12. Round bodies of $M$. xanthus $\left(12 \mathrm{hr}\right.$.) in $0.5 \mathrm{M}$-sucrose at $30^{\circ}$ after $120 \mathrm{~min}$. Phase contrast.

Fig. 13. Electron micrograph of a thin section of $M$. xanthus (12 hr.). Sections of cells 'rounded-up' in $0.5 \mathrm{M}$-sucrose at $30^{\circ}$ after $120 \mathrm{~min}$. Cells fixed in $2 \%(\mathrm{w} / \mathrm{v})$ formaldehyde. 
Journal of General Microbiology, Vol. 19, No. 1

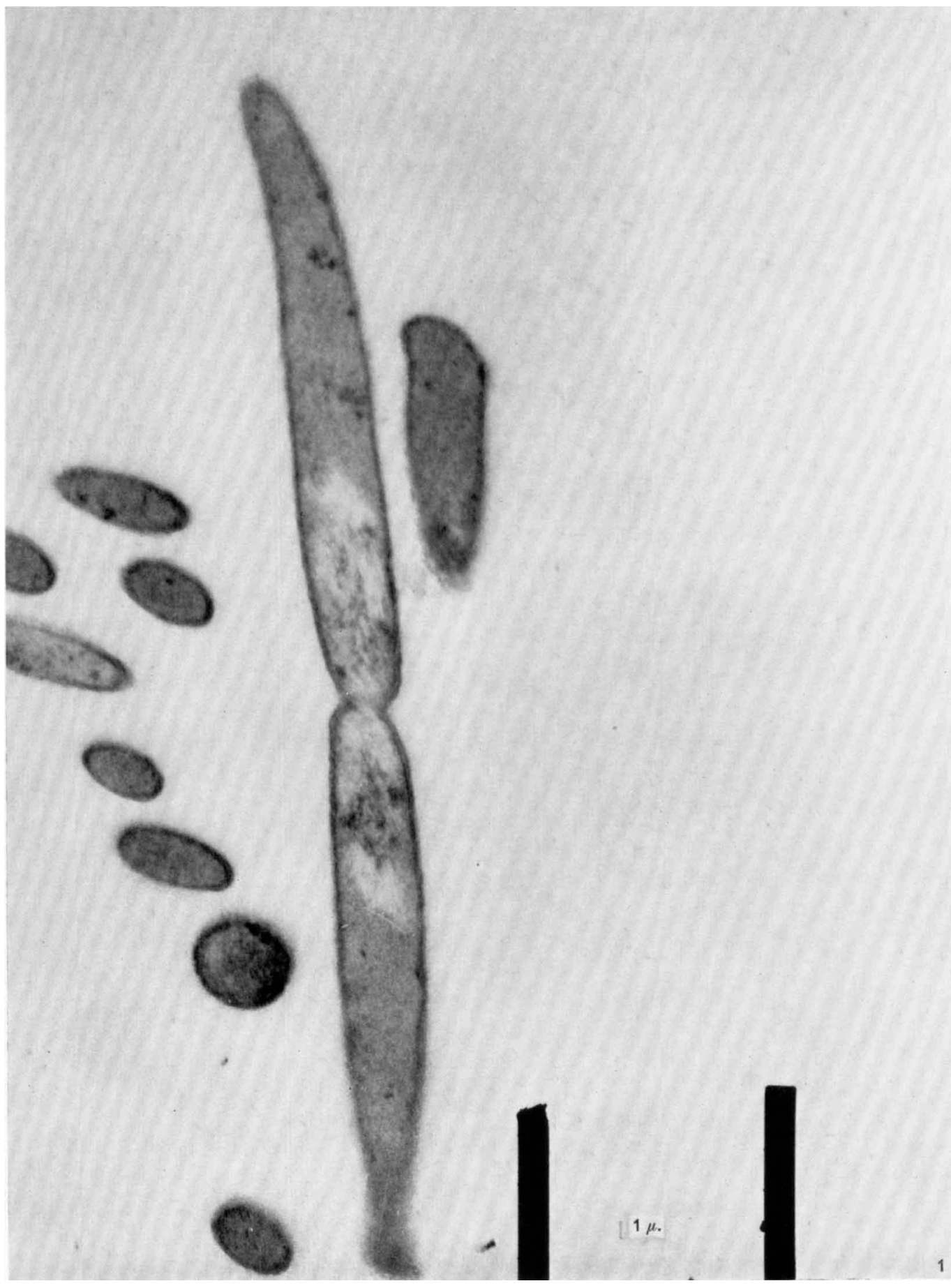

D. J. Mason \& D. Powelson-Lysis of myxococci. Plate 1 
Journal of General Microbiology, Vol. 19, No. 1

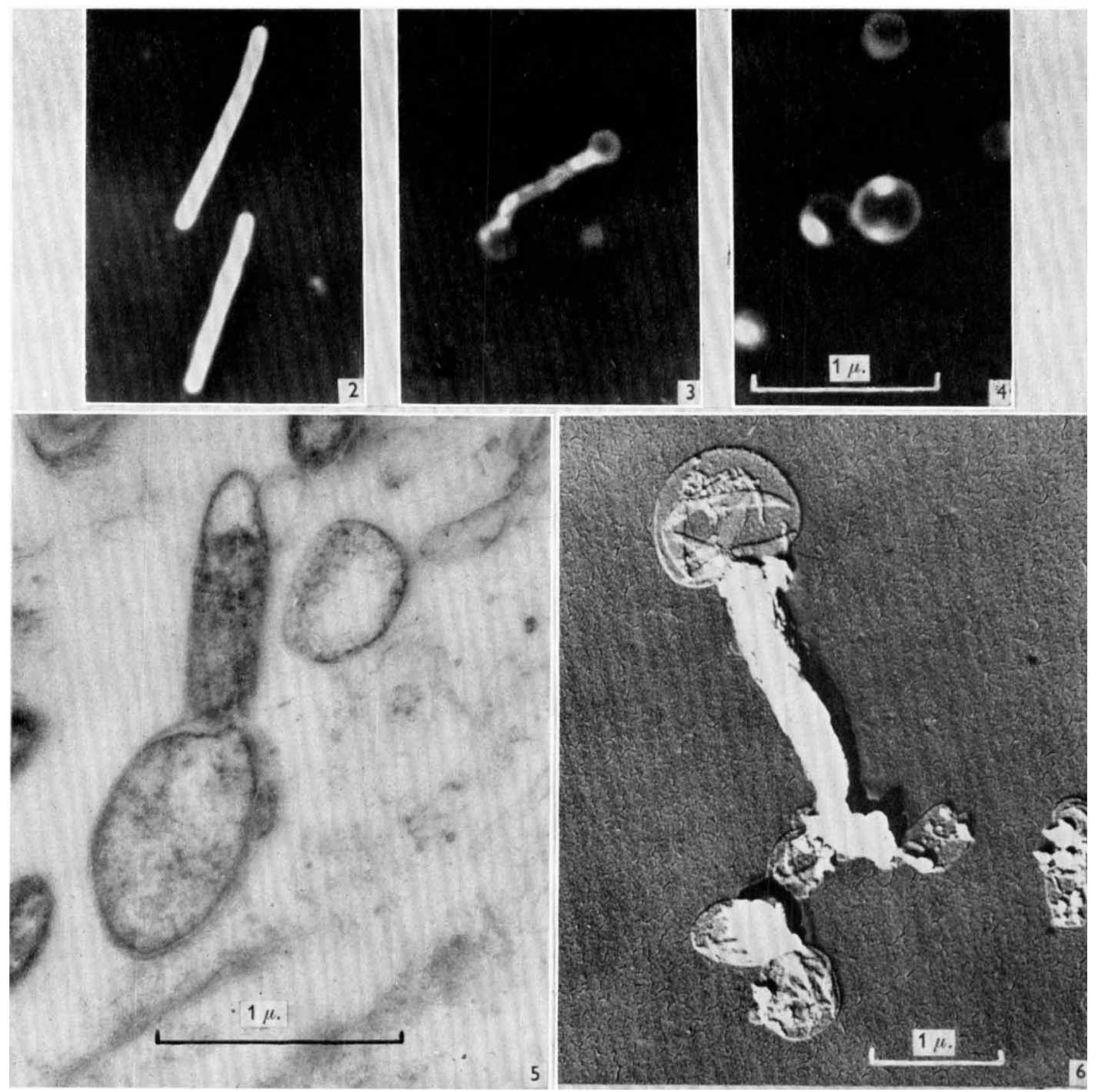

D. J. Mason \& D. Powelsun-Lysis of myxococci. Plate 2 
Journal of General Microbiology, Vol. 19, No. 1
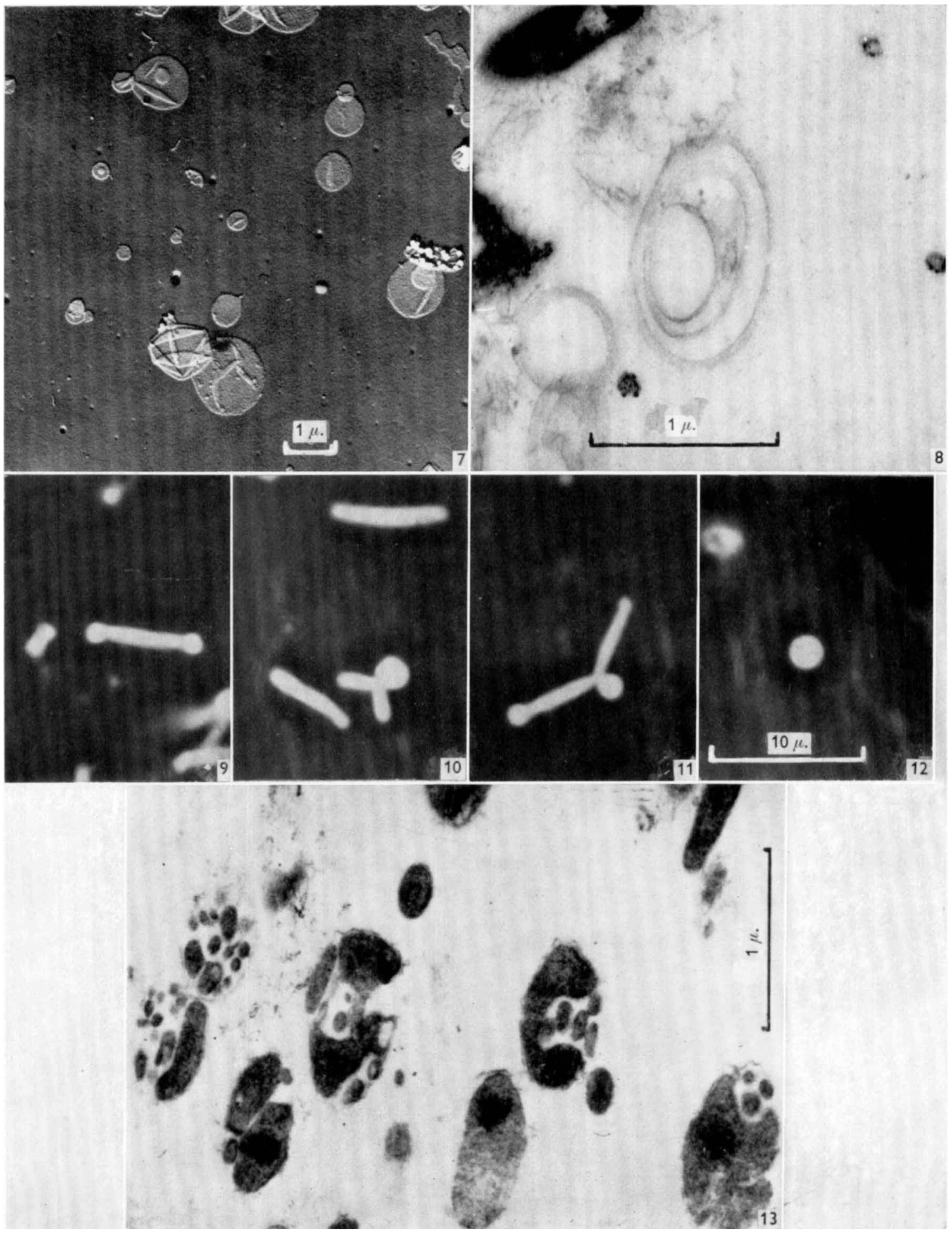

D. J. Mason \& D. Powelson-Lysis of myxococci. Plate 3 